\title{
Reflective Practices of English Teachers
}

\section{Sheila Mae M. Niones}

\author{
Bohol Is land State University - Clarin Campus \\ shel_sybe@yahoo.com
}

\begin{abstract}
Reflective teachers are effective teachers. With this notion, teachers have to practice reflective teaching inside their classes to emphasize that they are effective teachers. Since teachers' practices are not always expected to be reflective, this study discovered the junior high school English teachers' reflective teaching practices. It further investigated their reflective teaching practices through the help of their principals and students. This study is quantitative in nature. The findings revealed the English teachers' level of reflection, and their teaching practices. In-service English teachers need to undergo self-reflection to know more of themselves as teachers and to base modifications of classroom procedures. The school administration may conduct in-service training on reflective teaching practices since these in-service English teachers do not have any seminar-workshops on reflective teaching to develop themselves in their reflective teaching practices. Keywords - reflective teaching, teaching practices, inservice teachers, students, principals, quantitative study.
\end{abstract}

\section{INTRODUCTION}

The Philippines is part of United Nations Educational, Scientific, and Cultural Organization (UNESCO). This organization structured National Education for All (EFA) to accomplish the predetermined goals. One of the goals is to improve all aspects in quality education and ensure excellence so that learning outcomes are achieved by all specifically literacy, numeracy and essential life skills.Due to the country's unmet targets, Philippine EFA 2015 produces a National Plan of Action. In order to attain the sixth goal which is to achieve quality teaching, teachers have to promote practice of high quality teaching (Philippine EFA Review Report, 2015)[1].

In the DepEd Region 7, a Regional Memorandum No. 54 Series of 2016, dated January 25, 2016 was communicated to recognize the 2015 Harvest of Excellence Awards to Performing Schools Division Office. The Department of Education Region 7 held Harvest of Excellence Award Program last February 1, 2016. The activity aimed to recognize significant performance of Schools Divisions and School leaders. One of categories being recognized is the Level 8 Performance Based Bonus (PBB) in the secondary schools and divisions throughout the region. One of the qualifications to get a PBB is the MPS attained by the students in the school which may also reflect teachers' effectiveness. There were twelve (12) secondary schools recognized for the said category. Among the twelve (12), six (6) secondary schools are from Bohol, namely: Lila National High School (first in rank), Pres. Carlos P. Garcia Tech-Vocational School (second), Sikatuna National Agricultural High School (fourth), Handumon National High School (fifth), Cantubod National High School (seventh), and Hingotanan National High School (eighth).

If these schools got a PBB due to higher MPS, what do their teachers do attain such recognition? The question now is what do other teachers are doing that others are not doing? What others should be doing to attain higher MPS and achieve quality education? What makes a teacher effective?When teachers are reflectively questioning their own teaching practices, they will become more reflective classroom teachers. Reflection is a skill teachers need to go deeper and apply by heart because they mold young minds. Different situations will test what makes a teacher. Teachers must have this skill and acquire the ability to be reflective thinkers. More than that, applying it is the ultimate goal of an effective teacher. Effective teachers are truly effective because they are reflective thinkers.

Larrivee (2000)[2] mentioned that teachers need to realize that in their teaching profession they will be confronted continually with situations wherein they must make practical decisions. When an event or issue arises, the teachers need to realize that there is no prescribed checklist of how to respond (Mayes, 2001)[3]; they need to be able to determine an appropriate solution for that event or issue, which entails the process of reflective thinking.

Reflection is a skill necessary to possess to address abrupt situations affecting teaching-learning process. Since there is no study conducted yet related to this topic in the province of Bohol, the researcher selected the in-service English teachers in the Department of Education (DepED). These teachers have a minimum of five-year experience, 
because reflection is a skill learned overtime, to crisscross if reflective teaching is really practiced. Thus, the main purpose of this study was to determine the in-service English teachers' reflective teaching practices.

\section{OBJECTIVES OF THE STUDY}

The main purpose of this study was to determine the in-service English teachers' reflective teaching practices. Specifically, this study sought the reflective practices of the in-service English teachers along prereflection, surface reflection,pedagogical reflection, andcritical reflection; the teachers' teaching practices as viewed by students, and principals, and the significant difference on teachers' perceptions to reflective teaching practices as viewed by students and principals.

\section{Hypothesis}

This study hypothesized that there is significant difference on teachers' perceptions to reflective teaching practices as viewed by students and principals.

\section{Theoretical Framework}

This study focuses on one major theory: Barbara Larrivve's Levels of Reflection. According to Larrivve (2006)[4], being reflective is conscious reflection of the honest and moral implications and consequences of classroom practices with students. She mentioned that there are (4) four levels of reflection, namely: pre-reflection, surface reflection, pedagogical reflection, and critical reflection. Each level is being defined and characterized.

\section{MATERIALS AND METHODS}

A triangular approach with the use of questionnaires was used to achieve the said objective of this quantitative study. This is a descriptive correlational study.

The locales of the study were the junior high schools in the Department of Education (DepED) Bohol Division. There are three congressional districts under the Bohol Division. A total of fifty-one (51) schools in the province of Bohol were covered in the study: the thirteen (13) schools from the first district, eighteen (18) schools from second district, and twenty (20) schools from third district.

There were (3) three groups of respondents. The table below specifies the three groups.

Table.1: Research Respondents

\begin{tabular}{cccccccc}
\hline Congressional & No. of Junior & \multicolumn{2}{c}{ Principals } & \multicolumn{2}{c}{ Teachers } & \multicolumn{2}{c}{ Students } \\
\cline { 3 - 7 } District & High Schools & Distributed & Retrieved & Distributed & Retrieved & Distributed & Retrieved \\
\hline 1 & 13 & 32 & 20 & 32 & 28 & 320 & 304 \\
2 & 18 & 50 & 37 & 50 & 48 & 500 & 451 \\
3 & 20 & 42 & 38 & 42 & 40 & 420 & 366 \\
Total & 51 & 124 & 95 & 124 & 116 & 1240 & 1121 \\
\hline
\end{tabular}

The questionnaire includes the adapted "Survey of Reflective Practice: A Tool for Assessing Development as a Reflective Practitioner for Facilitators and Self-Assessment developed by Barbara Larrivee (2008)". This was answered by the in-service English teachers, their students and their principals. It is a rating scale: 5-often, 4-usually, 3sometimes, 2-rarely, and 1-never. It provides the reflective teaching practices categorized in four levels of reflection of the in-service English teachers. There are fourteen (14) items for pre-reflection, eleven (11) items for surface reflection, fourteen (14) items for pedagogical reflection, and fourteen (14) items for critical reflection. There are fifty-three (53) items in the questionnaire, and four (4) more items are blanked for additional inputs of the respondents.

The researcher secured the permission and approval of the schools division superintendent of the division of Bohol. Having the approval, the researcher administered the questionnaires to the in-service English teachers, principals, and students of the English teachers.

The data gathered were examined using Statistical Package for Social Studies (SPSS) for quantitative data. Weighted mean was utilized for the teaching practices and perceptions of the principals and students to the teaching practices of their teachers from the Rating Scale $(1-$ Never, 2 - Rarely, 3 - Sometimes, 4 - Usually, and 5 - Often) using the ranges 1:00-1.79, 1.80-2.59, 2.60-3.39, 3.40-4.19, and 4.20-5.00.

\section{RESULTS AND DISCUSSION}

Table 2 shows the in-service English teachers' standing in the levels of reflection in four (4) identified levels: pre-reflection in numbers 1 to 14 , surface reflection 
to 39 , and critical reflection in numbers 40 to 53 . This

Table.2: English Teachers' Reflective Teaching Practices

\begin{tabular}{|c|c|c|}
\hline As an English teacher, I ... & $\mathbf{W M}$ & Description \\
\hline 1. solve problems in the simplest way. & 3.93 & Usually \\
\hline 2. observe student and classroom conditions as beyond my control. & 2.32 & Rarely \\
\hline \multirow{2}{*}{\multicolumn{3}{|c|}{$\begin{array}{l}\text { 3. react immediately (words/actions) without thinking of other responses in my English } \\
\text { class. } \\
\text { 4.work based on fixed English standards without any idea from my students' responses. }\end{array}$}} \\
\hline & & \\
\hline 5. am a victim of the situations. & 1.95 & Rarely \\
\hline 6. support opinions and statements without evidences. & 1.94 & Rarely \\
\hline 7. blame the problems to students or others. & 1.88 & Rarely \\
\hline 8.take things/situations for granted without asking questions. & 1.58 & Never \\
\hline 9. feel nervous in supervising student obedience. & 1.50 & Never \\
\hline 10. reject students' views without appropriate thought. & 1.50 & Never \\
\hline 11.do not notice the instant demands in teaching English. & 2.07 & Rarely \\
\hline 12. do not consider the different needs of my students. & 1.65 & Never \\
\hline 13.do not connect my teaching actions with student behavior. & 1.53 & Never \\
\hline 14.pay no attention to the teamwork between teacher and students actions. & 1.41 & Never \\
\hline 15. adjust teaching practices based on the present situation. & 4.01 & Usually \\
\hline 16.teach English in different ways to attend students' differences. & 3.93 & Usually \\
\hline 17. support opinions with evidence from my experience. & 3.61 & Usually \\
\hline 18. adjust based on my past experience. & 3.55 & Usually \\
\hline 19. solve problems for instant results. & 3.17 & Sometimes \\
\hline 20. ask the value of specific and NOT the general teaching practices. & 2.73 & Sometimes \\
\hline 21. limit my English teaching practices to questions and techniques. & 2.56 & Rarely \\
\hline 22. change my English teaching strategies without testing expectations abo & & \\
\hline learning. & 2.18 & Rarely \\
\hline 23.do not connect my English teaching methods to theory. & 1.96 & Rarely \\
\hline $\begin{array}{l}\text { 24. answer student responses in different ways but I do NOT recognize } \\
\text { behavior. }\end{array}$ & 1.96 & Rarely \\
\hline 25. limit the students' ways or methods in learning. & 1.79 & Never \\
\hline 26.commit to endless learning and better practice. & 4.29 & Often \\
\hline 27.connect my English teaching practices to student learning. & 4.28 & Often \\
\hline 28.accept the problem of classroom is sues. & 4.27 & Often \\
\hline 29. acknowledge what students bring to the learning process. & 4.24 & Often \\
\hline 30. connect new concepts in English to students' previous learnings. & 4.22 & Often \\
\hline 31. am curious in the success of my teaching practices. & 4.21 & Often \\
\hline 32. adjust strategies based on students' performance. & 4.19 & Usually \\
\hline 33. identify other ways to represent ideas and concepts to students. & 4.18 & Usually \\
\hline 34. am open for review of my teaching practices. & 4.13 & Usually \\
\hline 35. participate in positive comments/review of my own teaching. & 4.08 & Usually \\
\hline 36.enhance the learning of my students. & 4.05 & Usually \\
\hline 37. see the effect of group activities in students' learning. & 3.97 & Usually \\
\hline 38. connectpatterns, and relationships to expand understanding. & 3.97 & Usually \\
\hline 39. consider students' decisions. & 3.91 & Usually \\
\hline
\end{tabular}


40. inspire responsible actions of my students.

41.know the difference between opinions and actions.

42. am fair in talking about problems that occur inside and outside the classroom.

43. think the right outcomes of classroom rules and habits.

44.admit that teaching practices and rules can influence or delay the achievement of a fair

and kind society.

45. ask and examine actively.

46. test tradition and expectations of students.

47. observe myself while thinking.

48.admit the social and political effects of my teaching.

49. know the rules and evidences of opinions.

50. identify opinions into question.

51. question existing rules and traditions.

52. practice in a larger social, cultural, historical, and political environment.

53. postpone decisions to think all options.

TOTALITY

$\begin{array}{ll}4.46 & \text { Often } \\ 4.29 & \text { Often } \\ 4.27 & \text { Often } \\ 4.01 & \text { Usually }\end{array}$

3.95 Usually

3.93 Usually

3.93 Usually

3.85 Usually

3.79 Usually

3.79 Usually

3.68 Usually

3.54 Usually

3.39 Sometimes

3.25 Sometimes

$3.21 \quad$ Sometimes

Legend: 1:00-1.79-Never 1.80-2.59-Rarely 2.60-3.39-Sometimes 3.40-4.19-Usually 4.20-5.00-Often

Item \#40, English teachers inspire responsible actions of students attains 4.46 which is 'often' practiced by the inservice English teachers. This means that the in-service English teachers frequently are modeling responsible actions for their students. These teachers believe that they themselves are role models inside and outside their classrooms. As the old adage says, actions speak louder than words.

Second in rank is Item \#41 which is English teachers know the difference between opinions and actions. The in-service English teachers 'often' practiced it with 4.29 as the mean. This means that these in-service English teachers can distinguish the differences between opinions and actions. Moreover, in this table, Item \#26: English teachers commit to endless learning and better practice is rated 4.29 with 'often' as its description. This means that the in-service English teachers frequently commit for improvement in the field of teaching. Since this is often, this is an established occurrence that this pedagogical reflection-item is practiced by the in-service English teachers. Problems are always occurring; this leads the inservice English teachers to find ways to better help themselves in the teaching profession. According to Larrivve (2008)[5], in this level, the teacher is continuously thinking about in what way teaching practices are moving students' learning and in what way to improve learning experiences. The teachers' aim is endlessly refining practice and getting all students.

Third in rank is Item \#27, English teachers connect English teaching practices to student learning. This is also 'often' practiced with 4.28 as its mean. This means that the in-service English teachers find ways to link their teaching practices to student learning.

\section{Teachers' Level of Reflection}

This portion ranks which among Larrivee's levels of reflection do these in-service English teachers fall. This also highlights if the in-service English teachers achieve the uppermost level of reflection, critical reflection.

Table.3: Teachers' Level of Reflection

\begin{tabular}{lccc}
\hline \multicolumn{1}{c}{ Levels of Reflective Practices } & WM & Description & Rank \\
\hline 1. Pre-reflection & 1.98 & Rarely \\
2. Surface Reflection & 2.86 & Sometimes & 3 \\
3. Pedagogical Reflection & 4.14 & Usually & 1 \\
4. Critical Reflection & 3.87 & Usually & 2 \\
\hline Totality & 3.21 & Sometimes \\
\hline
\end{tabular}

Legend: 1:00-1.79-Never 1.80-2.59-Rarely 2.60-3.39-Sometimes 3.40-4.19-Usually 4.20-5.00 - Often 
In this table, it clearly shows that the in-service English teachers usually practice the pedagogical reflection, as ranked first. Pedagogical Reflection or reflection-on-action is the third level of reflection. The core emphasis here is to apply educational knowledge to determine a basis for practice (Weber, 2013)[6]. The teacher relates strategies used to beliefs because his/her definite goal is to constantly educating practice and getting all students. He/she strives for consistency between theory and theory-in-use. Principles and situations around teaching are precise and reinforced by proof from experience and theory or research. $\mathrm{He} / \mathrm{she}$ also strives to understand theoretical basis for instruction and apply various theories, knowledge and research practices. He/she is also up-to-date on current research on quality, and best practices because in this level the teacher is continually discerning approximately exactly how teaching practices are moving students' learning and exactly how to augment learning experiences. He/she wants to focus on continuous improvement and enhancing student learning, and their teaching positions are always supported by experience including theory and research. His/her reflection is directed by educational theoretical context. The teacher's vision of teaching and learning is multidimensional relating events within a wider context (Larrivve, 2008)[7].

Students' Views of the Teachers' Teaching Practices

Table 4 shows the teaching practices of the inservice English teachers as viewed by their students. These students are the direct beneficiaries of the reflective teaching practices of these in-service English teachers.

Table.4: Students' Views on their Teachers' Practices

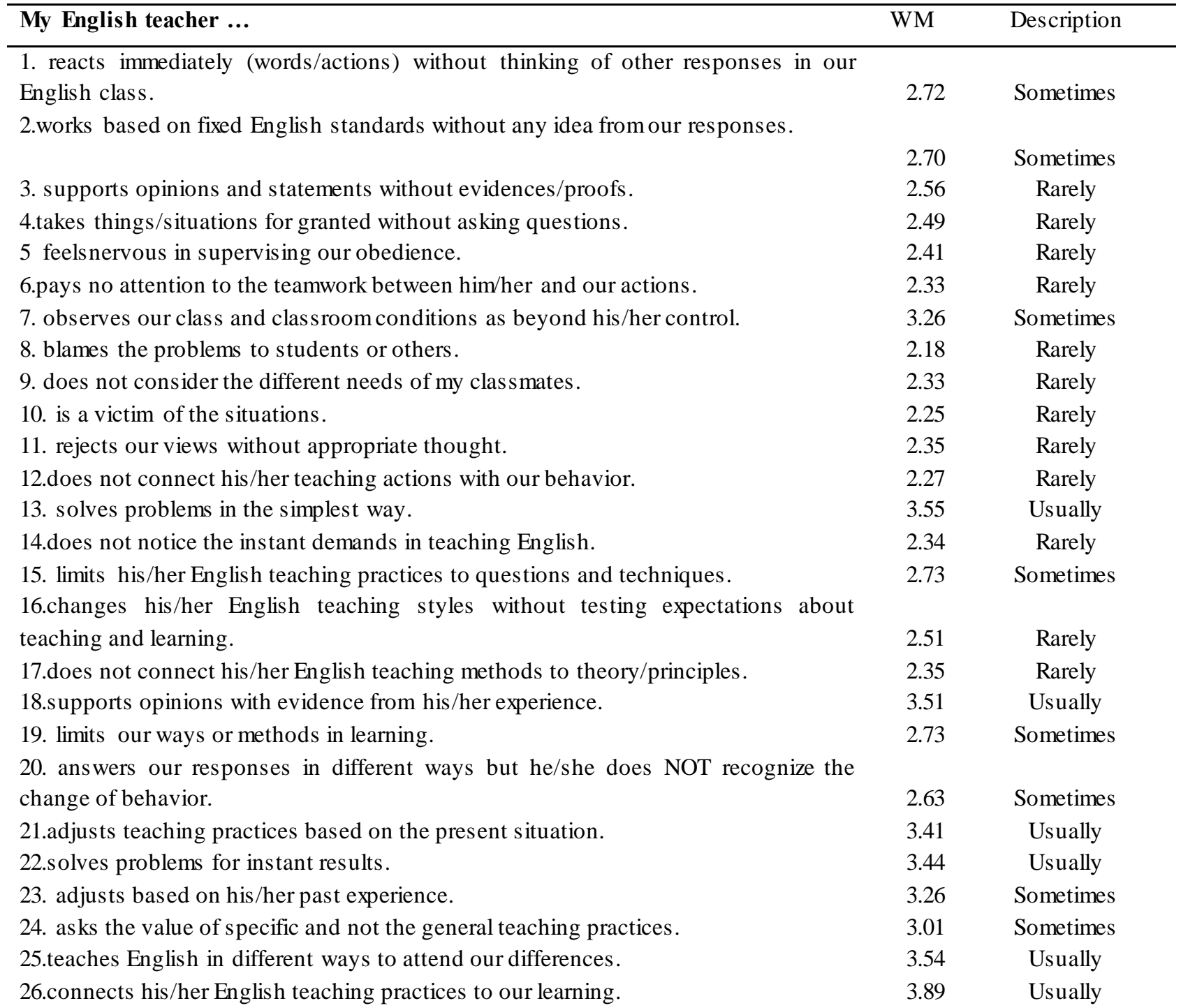


27.enhances our learning in English.

28.connects new concepts in English to our previous learnings.

29. is curious in the success of his/her English teaching practices.

30. participates in positive comments/review of his/her own teaching.

31.adjusts strategies based on our performance.

32.sees the effect of group activities in our learning.

33. connects patterns, and relationships to expand our understanding.

34.commits to endless learning and better practice.

35 identifies other ways to represent ideas and concepts.

36.accepts the problem of English classroom is sues.

37.acknowledges what we bring to the learning process.

38.considers our decisions.

39. is open for review of his/her teaching practices.

40. practices in a larger social, cultural, historical, and political environment.

41. thinks the right outcomes of English classroom rules and habits.

42. is fair in talking about problems that occur inside and outside the classroom.

43.questions existing rules and traditions.

44. observes himself/herself while thinking.

45.knows the difference between opinions and actions.

46.admits the social and political effects of his/her English teaching.

47. asks and examines actively.

48. tests our traditions and expectations.

49. postpones decisions to think all options.

50. knows the rules and evidences of opinions.

51. identifies opinions into question.

52.admits that teaching practices and rules can influence or delay the achievement of a fair and kind society.

53. inspires our responsible actions.

$\begin{array}{ll}4.01 & \text { Usually } \\ 3.78 & \text { Usually } \\ 3.42 & \text { Usually } \\ 3.60 & \text { Usually } \\ 3.62 & \text { Usually } \\ 3.70 & \text { Usually } \\ 3.83 & \text { Usually } \\ 3.46 & \text { Usually } \\ 3.60 & \text { Usually } \\ 3.48 & \text { Usually } \\ 3.58 & \text { Usually } \\ 3.69 & \text { Usually } \\ 3.69 & \text { Usually } \\ 3.41 & \text { Usually } \\ 3.76 & \text { Usually }\end{array}$

$3.41 \quad$ Usually

$4.31 \quad$ Often

$3.36 \quad$ Sometimes

$3.64 \quad$ Usually

3.27 Sometimes

3.67 Usually

3.36 Sometimes

3.02 Sometimes

3.54 Usually

$3.36 \quad$ Sometimes

TOTALITY 3.15
3.53 Usually

3.83 Usually

Legend: 1:00-1.79-Never 1.80-2.59-Rarely 2.60-3.39-Sometimes 3.40-4.19-Usually 4.20-5.00-Often

In terms of teaching effectiveness of the in-service English teachers, their students viewed Item \#43: My English teacher questions existing rules and traditions 'often' with a mean of 4.31. This means that the students observed their in-service English teachers frequently in questioning existing rules and traditions.

Second in rank is Item \# 27: My English teacher enhances our learning in English is rated 'usually' with a mean of 4.01. This means that these students of the inservice English teachers view them as very regular in enhancing students' learning in their English class. This item is part of the pedagogical reflection of Larrivee (2008)[9].

Third in rank is Item \#26: My English teacher connects his/her English teaching practices to our learning.
This is done 'usually' with a mean of 3.89 . This means that the students view their in-service English teachers as very regular in connecting teaching to learning. These students see their in-service English teachers performing different ways just to link teachers' teaching practices to their own learning.

Principals' Views of the Teachers' Teaching Practices

Table 5 highlights the standing of the in-service English teachers when it comes teaching practices of their reflective practices as viewed by their superiors, the principals. These principals are their direct supervisors of their reflective teaching practices. 


\begin{tabular}{l} 
The Englis h teacher ... \\
\hline 1. reacts immediately (words/actions) without thinking of other responses in his/her
\end{tabular}
English class.

2.works based on fixed English standards without any responses from his/her students.

3. supports opinions and statements without evidences.

4.takes things/situations for granted without asking questions.

5 feels nervous in supervising student obedience.

6.pays no attention to the teamwork between teacher and students actions.

7. observes student and classroom conditions as beyond his/her control.

8. blames the problems to students or others.

9. does not consider the different needs of his/her students.

10. is a victim of the situations.

11. rejects students' views without appropriate thought.

12.does not connect his/her teaching actions with student behavior.

13. solves problems in the simplest way.

14.does not notice the instant demands in teaching English.

15. limits his/her English teaching practices to questions and techniques.

16.changes his/her English teaching styles without testing expectations about teaching and learning.

17.does not connect his/her English teaching methods to theory/principles.

18.supports opinions with evidence from his/her experience.

19. limits the students' ways or methods in learning.

20. answers student responses in different ways but he/she does NOT recognize the change of behavior.

21.adjusts teaching practices based on the present situation.

22.solves problems for instant results.

23. adjusts based on his/her past experience.

24 . asks the value of specific and not the general teaching practices.

25.teaches English in different ways to attend students' differences.

26.connects his/her English teaching practices to student learning.

27.enhances the learning of his/her students.

28.connects new concepts in English to students' previous learnings.

29.is curious in the success of his/her teaching practices.

30. participates in positive comments/review of his/her own teaching.

31.adjusts strategies based on students' performance.

32.sees the effect of group activities in students' learning.

33. connects patterns, and relationships to expand understanding.

34.commits to endless learning and better practice.

35. identifies other ways to represent ideas and concepts to students.

36.accepts the problem of classroom is sues.

37.acknowledges what students bring to the learning process.

38.considers students' decisions.

39. is open for review of his/her teaching practices.

40. practices in a larger social, cultural, historical, and political environment.

41. thinks the right outcomes of class room rules and habits.

42. is fair in talking about problems that occur inside and outside the classroom.

43.questions existing rules and traditions.

\section{WM Description}

2.18 Rarely

2.27 Rarely

2.37 Rarely

2.03 Rarely

2.80 Sometimes

2.60 Sometimes

2.45 Rarely

2.21 Rarely

1.79 Never

2.06 Rarely

2.01 Rarely

2.25 Rarely

2.90 Sometimes

2.20 Rarely

2.39 Rarely

2.33 Rarely

2.44 Rarely

3.02 Sometimes

2.63 Sometimes

2.45 Rarely

2.78 Sometimes

2.57 Rarely

2.79 Sometimes

2.61 Sometimes

2.77 Sometimes

3.06 Sometimes

3.02 Sometimes

3.03 Sometimes

2.87 Sometimes

2.87 Sometimes

2.95 Sometimes

3.17 Sometimes

3.11 Sometimes

3.11 Sometimes

3.03 Sometimes

3.04 Sometimes

3.00 Sometimes

2.77 Sometimes

2.95 Sometimes

2.84 Sometimes

3.13 Sometimes

3.20 Sometimes

2.69 Sometimes 
44. observes himself/herself while thinking.

45.knows the difference between opinions and actions.

46.admits the social and political effects of his/her English teaching.

47. asks and examines actively.

48. tests tradition and expectations of students.

49. postpones decisions to think all options.

50. knows the rules and evidences of opinions.

51. identifies opinions into question.

52.admits that teaching practices and rules can influence or delay the achievement of a fair and kind society.

53. inspires responsible actions of his/her students.
2.62 Sometimes

3.07 Sometimes

3.02 Sometimes

2.93 Sometimes

2.62 Sometimes

2.71 Sometimes

2.86 Sometimes

2.76 Sometimes

\subsection{Sometimes}

3.06 Sometimes

$2.75 \quad$ Sometimes

Legend: 1:00-1.79-Never 1.80-2.59-Rarely 2.60-3.39-Sometimes 3.40-4.19-Usually 4.20-5.00 - Often

Item \#42: The English teacher is fair in talking about problems that occur inside and outside the classroom ranks first among the teaching practices of the in-service English teachers. According to the principals, the superiors of these in-service English teachers, this item is 'sometimes' practiced with a mean of 3.20. This means that the inservice English teachers treat people in a way that does not favor some over others. Again, favoritism should not be an issue for these in-service English teachers. They are impartial individuals to avoid biases and prejudices to discern fairness and equity. As observed by the principals, these in-service English teachers are fair.

Second in rank is Item \#32: The English teacher sees the effect of group activities in students' learning. This item is included in the pedagogical reflection of these inservice English teachers. This is viewed by the principals as 'sometimes' practiced' with a mean of 3.17. This means that principals viewed group dynamics as helpful in student's learning; these in-service English teachers also are enthusiasts of group dynamics. This result is supported by Teaching Practices, Teachers' Beliefs and Attitudes (2009)[11] that teachers in diverse areas of the world on average permit student cooperative purpose of the class employ capability consortium. It contributes students' exclusively modified tasks than they allocate for students' projects, debates, essays and products. Thus, these inservice English teachers are employing groupings with their students.

Next in rank is Item \#41: The English teacher thinks the right outcomes of classroom rules and habits. This is part of the critical reflection of Larrivee (2008)[12]. The principals viewed this also 'sometimes' practiced with a mean of 3.13. This means that the principals of these inservice English teachers perceived them as thinkers in coming up with the right results of classroom rules and habits. An English teacher is a thinker to model their thinking skills to their students and to encourage them to be thinkers while they are still young. They cannot hone this skill to their students if they are not thinkers too.

Teachers' Perceptions on Teaching Reflective Practices as viewed by Students and Principals

Table 6 showcases the differences of the in-service English teachers' reflective teaching practices to the perception on teaching reflective practices viewed by their students and principals.

\begin{tabular}{cccccc}
\multicolumn{4}{c}{ Table.6: Teachers' Perceptions on Teaching Reflective Practices as viewed by Students and Principals } \\
$\begin{array}{c}\text { Perception on } \\
\begin{array}{c}\text { Teachers' Teaching } \\
\text { Practices }\end{array}\end{array}$ & $\begin{array}{c}\text { Teachers' } \\
\text { Reflective } \\
\text { Teaching Practices }\end{array}$ & $\begin{array}{c}\text { Mean } \\
\text { Difference } \\
\text { (Gain/Loss) }\end{array}$ & t-value & p-value & Description \\
Students $=3.15$ & 3.21 & 0.06 & 3.008 & 0.000 & Not significant \\
Principals $=2.75$ & 3.21 & 0.46 & -1.33 & 0.312 & Significant
\end{tabular}


The difference of the in-service English teachers' reflective practices and students' perception of their teaching practices is not significant as viewed by the students of the in-service English teachers. There is a loss of 0.06 in its mean difference. This means that as viewed by the students reflective teaching practices do not differ to the teaching practices practiced by these in-service English teachers. This further means that the students who are always with the in-service English teachers view the same practices of their teachers. The result is comparable since they are always together, and the students themselves can commend and attest to these practices which are really practiced by the in-service English teachers. According to Stark (2013)[13], students are in good position to evaluate some aspects of teaching.

On the other hand, there is a significant difference of the in-service English teachers' reflective practices and principals' perception of their teaching practices. There is a loss of 0.46 in its mean difference. This means that the principals' view reflective teaching practices differ on the reflective teaching practices of these in-service English teachers. This significant difference tells that the in-service English teachers rated themselves differently on their teaching practices in comparison to the principals' perception of their teaching practices. This means that the in-service English teachers rated themselves higher than their principals' perception of their teaching practices. This is expected since the in-service English teachers rated themselves higher since this is a self-assessment which is prone to subjectivity while the principals, the superiors of these in-service English teachers, a greater chance of objectively was used in rating these in-service English teachers.

\section{CONCLUSIONS AND RECOMMENDATIONS}

Reflective teaching practices of the in-service English teachers do not reach the highest level of Larrivee's levels of reflection. This is reflected by the views of the students and principals of the in-service English teachers. Teachers' account on their teaching practices, as asked, offer different views from the in-service English teachers that the lack of idea on reflective teaching is ascertained. In relation to the results of the study, the researcher recommends the following: Teacher education programs must have reflective teaching designs to prepare pre-service English teachers. In-service English teachers need to undergo self-reflection to know more of themselves as teachers and to base modifications of classroom procedures. The school administration may conduct in-service training on reflective teaching practices since these in-service English teachers do not have any seminar-workshops on reflective teaching. Action researches may be accomplished to provide empirical evidences on the improvement of the reflective teaching practices of these in-service English teachers.

\section{ACKNOWLEDGEMENT}

Commission on Higher Education K-12 Transition Program Scholarship- Dissertation Grant

\section{REFERENCES}

[1] Philippine EFA Review Report (2015)

[2] Larrivee, B. (2000). Transforming teacher practice: Becoming the critically reflective teacher. Reflective Practice, 1(3), 293-307.

[3] Mayes, C. (2001). Deepening our reflectivity.The Teacher Educator, 36(4), 248- 264.

[4] Larrivvee, B. (2006). An educator's guide to teacher reflection. Boston, MA: Houghton Mifflin Company.

[5] Larrivee, B. (2008). Development of a tool to assess teachers' levels of reflective practice. Reflective Practice, 9(3), 341-360.

[6] Weber, S. S. (2013). Can preservice teachers be taught to become reflective thinkers during their first internship experience? Unpublished Dissertation. Liberty University, Lynchburg, VA

[7] Larrivee, B. (2008). Development of a tool to assess teachers' levels of reflective practice. Reflective Practice, 9(3), 341-360.

[8] Ibid.

[9] Teaching Practices, Teachers' Beliefs and Attitudes. (2009). Creating Effective Teaching and Learning Environments

[10] Larrivee, B. (2008). Development of a tool to assess teachers' levels of reflective practice. Reflective Practice, 9(3), 341-360.

[11] Stark, Philip (2013). Do student evaluations measure teaching effectiveness? 